Published by LPMP Imperium

Journal homepage: https:/ / ejournal.imperiuminstitute.org/index.php/ AKURASI

\title{
Pengaruh Fundamental Perusahaan Terhadap Kesehatan Bank Melalui Pembiayaan Bank Muamalat Indonesia
}

\section{Thariq Atul Himah}

Akuntansi, Fakultas Ekonomi dan Bisnis Islam, IAIN Tulungagung

\section{Research Paper \\ Islamic Finance}

\section{Abstract}

The aim of this resesearch is to indicate and analyze the determinants of the health of indonesian muamalat bank in 2009 - 2018. Bank health is dependent variable in this research. There are six independent variabels that used, wich are CAR, NPF, ROA, NIM, BOPO, FDR and the intervening variable which is financing. The data analyzed with path analysing using spss program. The results showed that partially CAR, NPF, ROA, NIM, BOPO and FDR had no significant effect on bank health. CAR, NPF, ROA, NIM, BOPO, FDR and financing simultaneously have a significant effect on bank health. But financing can mediate between variable independent CAR, NPF, ROA, NIM, BOPO and FDR to bank health.

\section{Keywords:}

Bank Health, Indonesian Muamalat Bank, Financing

\section{Corresponding Author:}

Thariq Atul Himah

Akuntansi, Fakultas Ekonomi dan Bisnis Islam, IAINTulungagung

Jl. Mayor Sujadi Timur 46 Tulungagung

Email: thoriqatul@gmail.com

(C) The Author(s) 2021

DOI: https:/ / doi.org/ 10.36407/ akurasi.v3i1.249

Received: 13 Nov 2020

Revised: 28012021

Accepted: 30012021

Online: 19 Feb 2021

Akurasi: Jurnal Riset Akuntansi dan Keuangan, Vol 3, No.1, 2021, pp. $1-16$

eISSN 2685-2888

\section{(c) (1)}

CC BY: This license allows reusers to distribute, remix, adapt, and build upon the material in any medium or format, so long as attribution is given to the creator. The license allows for commercial use. 


\section{PENDAHULUAN}

Semakin majunya perekonomian Indonesia tidak lepas dari peran industri perbankan dalam membantu kemajuan perekonomian. Bank memiliki peran sangat penting dalam perekonomian. Peran tersebut ialah sebagai sarana menghimpun dan menyalurkan dana secara efektif dan efisien untuk peningkatan taraf hidup rakyat atau sebagai perantara antara pihak yang membutuhkan dana dengan pihak yang memiliki kelebihan dana dimana pihak yang mempunyai dana lebih akan melakukan kegiatan menabung sedangkan yang kekurangan dana akan melakukan kegiatan kredit (Luciana dan Winny, 2005;2-3).

Seiring semakin banyaknya industri perbankan, maka pengawasan terhadap bank perlu dilakukan untuk mengetahui tingkat kesehatan perbankan. Kesehatan bank diartikan sebagai kemampuan suatu bank dalam melakukan kegiatan operasional secara normal dan mampu memenuhi segala kewajibannya dengan baik sesuai peraturan yang berlaku. Berdasarkan Peraturan SE BI Pasal 3 No 9/1/ PBI/ 2007 Tingkat kesehatan bank adalah hasil penelitian kualitatif dari berbagai aspek yang berpengaruh pada kondisi bank melalui penilaian kuantitatif dan kualitatif terhadap faktor permodalan, kualitas aset, rentabilitas, likuiditas dan sensitivitas terhadap risiko pasar dan penilaian kualitatif terhadap faktor manajemen (Ramlan,2012;27-29). Pengukuran terhadap kondisi kesehatan bank dapat dilihat dari analisis fundamentalnya yaitu dari rasio-rasio keuangan diantaranya Capital Adequacy Ratio (CAR), Non Performing Financing (NPF), Return on Assets (ROA), Net Income Margin (NIM), Beban Operasional terhadap Pendapatan Operasional (BOPO) dan Financing to Deposits Ratio (FDR).

Dalam penelitian ini tinggi rendahnya nilai rasio keuangan Capital Adequacy Ratio (CAR), Non Performing Financing (NPF), Return on Assets (ROA), Net Income Margin (NIM), Beban Operasional terhadap Pendapatan Operasional (BOPO) dan Financing to Deposits Ratio (FDR) akan berpengaruh pada kegiatan usaha bank dimana tentunya hal tersebut akan berpengaruh terhadap tingkat kesehatan suatu perbankan. Kredit atau dalam bank syariah menyebutnya dengan pembiayaan merupakan salah satu pendapatan utama suatu perbankan, karena kredit (pembiayaan) memberikan keuntungan yang lumayan besar dibandingkan dengan lainnya, seperti biaya jasa dana tabungan, biaya jasa pengiriman antarbank dan lainnya (Susan dan lela, 2014;83). Sesuai dengan teori Risk Bearing Theory of Profit ialah perusahaan akan mendapatkan laba diatas normal, jikalau jenis usaha tersebut mempunyai risiko yang tinggi dan pembiayaan adalah kegiatan usaha perbankan yang memiliki risiko tinggi (Ulin dan Astiwi, 2016;2).

Gambar 1 menunjukkan pergerakan jumlah Pembiayaan Bank Muamalat Indonesia periode 2008-2018 terlihat stabil. Adapun Faktor yang memengaruhi kenaikan pembiayaan ialah Dana Pihak Ketiga, tingkat bagi hasil, FDR, CAR, ROA, NPF, semakin tinggi faktor tersebut maka pembiayaan juga semakin meningkat begitu juga sebaliknya. Melihat kondisi positif inilah, maka peneliti untuk melakukan penelitian lebih lanjut apakah variabel pembiyaan dapat dijadikan sebagai variabel intervening (mediasi) untuk mengetahui pengaruh tidak langsung CAR, NPF, ROA, NIM, BOPO dan FDR terhadap kesehatan bank pada Bank Muamalat Syariah dalam periode 2009-2018. 


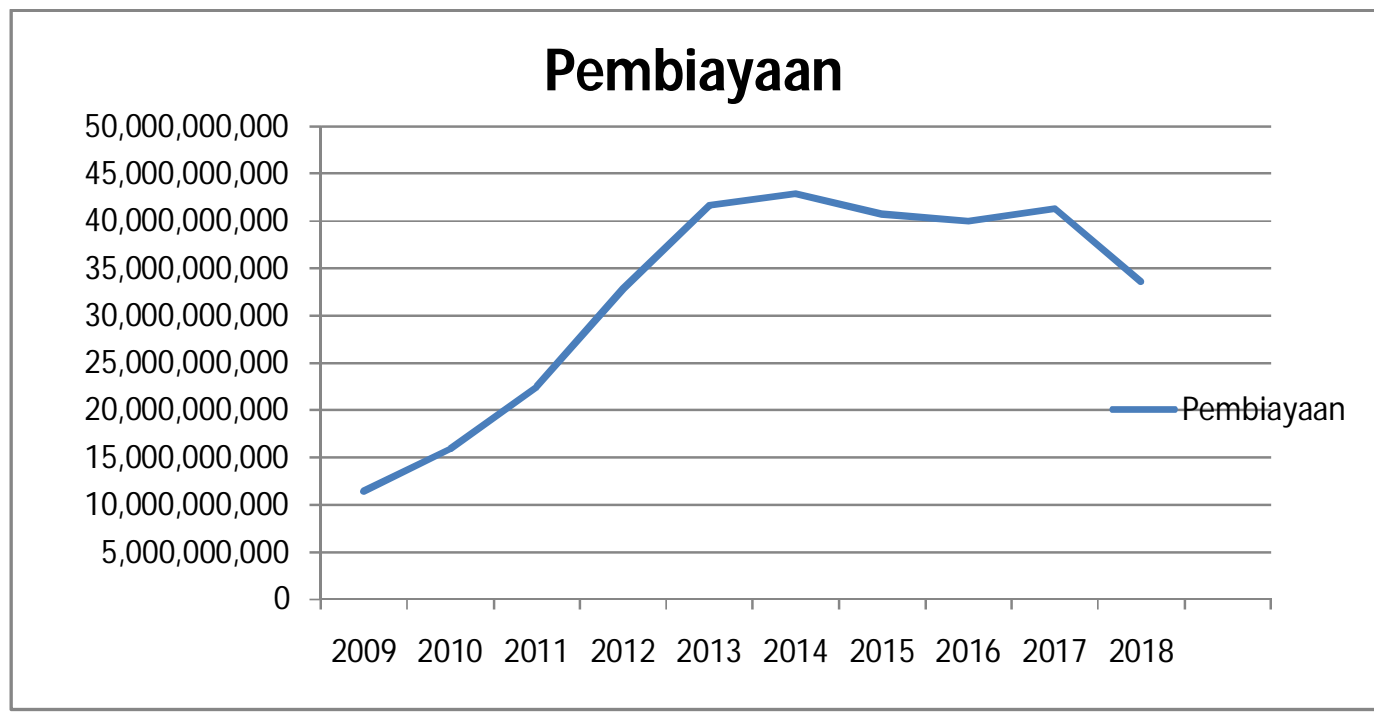

\section{Gambar 1}

Pergerakan Jumlah Pembiayaan Tahun 2009 - 2018

Keterbaruan dalam penelitian ini adalah terdapat variabel intervening yaitu berupa variabel pembiayaan, dimana variabel intervening digunakan sebagai perantara (menjembatani) hubungan variabel independen ke variabel dependen dalam hubungan yang tidak langsung, tidak dapat diukur atau diamati. Pemilihan variabel kredit (pembiayaan) karena memberikan keuntungan yang lumayan besar dibandingkan dengan lainnya, seperti biaya jasa dana tabungan, biaya jasa pengiriman antarbank dan lainnya (Susan dan lela, 2014;83). Mengingat beberapa penelitian terdahulu yaitu dari Luciana dan Winny (2005), Nanang dan Sutapa (2010), Diana dan Yuniningsih (2020), titik dan Balafif (2007) tentang pengaruh fundamental terhadap kesehatan bank hasil penelitiannya berbeda-beda ada yang signifikan ada yang tidak signifikan, sehingga penelitian ini penting untuk dilakukan dengan ditambahkan variabel intervening agar hasil yang didapatkan signifikan atau memengaruhi variabel independen terhadap variabel dependen menjadi hubungan yang tidak langsung. Dila Angraini (2018) melakukan penelitian tentang pengaruh DPK, NPF, Tingkat bagi hasil dan modal sendiri terhadap Profitabilitas dengan variabel intervening pembiayaan bagi hasil pada bank syariah dan mendapati hasil bahwa variabel pembiayaan mampu memediasi NPF dan tingkat bagi hasil terhadap profitabilitas. Hal ini mengindikasikan kemungkinan pembiayaan juga memengaruhi hubungan pengaruh antara fundamental terhadap kesehatan bank. Objek penelitian diambil Bank Muamalat Syariah karena bank tersebut merupakan bank yang pertama kali menerapkan prinsip syariah dan pertumbuhannya cukup signifikan.

\section{KAJIAN PUSTAKA}

\section{Fundamental Perusahaan}

Analisis fundamental ialah suatu usaha untuk memprediksi kesehatan dan kemajuan laba perusahaan, yaitu kemampuan dalam perusahaan untuk tumbuh dan dapat menghasilkan laba dimasa depan. Salah satu aspek yang paling dominan dari fundamental adalah tentang analisis laporan keuangan, karena didalamnya mampu memprediksi suatu keadaan atau posisi dan arah perusahaan (Teguh Jiwandono, 2014;785). Berdasarkan aspek aspek 
fundamental dapat dinilai dalam rasio-rasio keuangan, adapun rasio yang digunakan antara lain CAR, NPF, ROA, NIM, BOPO dan FDR.

\section{Kesehatan Bank}

Kesehatan Bank adalah kemampuan suatu perbankan dalam melaksanakan kegiatan operasionalnya serta mampu memenuhi segala kewajibannya disesuaikan dengan peraturanperaturan perbankan yang berlaku. Bank bisa dikatakan sehat yaitu bank yang dapat menjalankan fungsinya dengan baik, bank yang bisa menjaga serta memelihara kepercayaan dari masyarakat, serta dapat digunakan oleh pemerintah dalam menjalankan kebijakannya terutama kebijakan moneter.(Diana Nurhayati dan Yuniningsih yuniningsih, 2020;33).

\section{Pembiayaan}

Istilah pembiayaan biasanya dikenal dalam perbankan syariah, atau masyarakat biasanya menyebutnya hutang piutang atau kredit. Seseorang yang meminjamkan hartanya kepada orang lain maka itu disebut hutang piutang. Pembiayaan atau financing adalah kegiatan penyaluran dana kepada suatu pihak lain untuk mendukung perencanaan kegiatan investasi baik yang dilakukan sendiri maupun lembaga. Menurut UU Nomor 10 Tahun 1998 disebutkan bahwa pembiayaan berdasarkan prinsip syariah adalah penyediaan uang atau tagihan yang dipersamakan dengan itu, berdasarkan persetujuan atau kesepakatan pinjam meminjam antara bank dengan pihak lain yang mewajibkan pihak yang dibiayai untuk mengembalikan uang atau tagihan tersebut setelah jangka waktu tertentu dengan imbalan atau bagi hasil (Muhammad, 2005;17)

\section{Pengaruh Rasio CAR terhadap Kesehatan Bank}

Penilaian tingkat kesehatan bank adalah dengan melalui rasio-rasio keuangan diantaranya yaitu CAR menunjukkan kecukupan modal bank dalam menanggung risiko yang ditimbulkan perbankan. Semakin tinggi nilai CAR maka semakin rendah kemungkinan suatu bank mengalami kondisi bermasalah. Karena memiliki kecukupan modal untuk melakukan kegiatan operasionalnya dan mampu menanggung risiko yang mungkin timbul ketika menjalankan kegiatannya. Dalam penelitian yang dilakukan oleh Almilia dan Herdiningtyas (2005) bahwa terdapat pengaruh yang signifikan antara rasio CAR terhadap kondisi bermasalah perbankan, berbeda dengan penelitian Wahyudi dan Sutapa (2010) bahwa variabel tersebut tidak berpengaruh signifikan terhadap kesehatan bank.

H1 : Rasio CAR secara parsial berpengaruh positif terhadap Kesehatan Bank.

\section{Pengaruh Rasio NPF terhadap kesehatan bank}

NPF menunjukkan kualitas aset untuk menilai kondisi suatu aset bank, yaitu mengantisipasi risiko gagal bayar dari pembiayaan. Semakin tinggi rasio ini menunjukkan ketidakmampuan perbankan dalam mengelola pembiayaan bermasalahnya dan mengakibatkan penurunan tingkat kepercayaan suatu investor terhadap bank serta berpengaruh pada kesehatan bank. Hasil penelitian dari Diana Nurhayati dan Yuniningsih Yininingsih (2020) mengenai rasio NPF berdasarkan hasil analisis diskriminan bahwa rasio NPF mempunyai koefisien tertinggi dalam pembentukannya.

H2:Rasio NPF secara parsial berpengaruh positif terhadap Kesehatan Bank. 
Thariq Atul Himah

Bank Health, Indonesian Muamalat Bank, Financing

\section{Pengaruh Rasio ROA terhadap kesehatan bank}

ROA digunakan untuk mengukur kemampuan suatu manajemen bank dalam mendapatkan laba yang terdapat dari rata-rata total aset bank yang bersangkutan. Semakin besar ROA semakin besar pula keuntungan yang didapat, sehingga kondisi bank semakin sehat. Hasil penelitian Wahyudi dan Sutapa (2010) mengenai rasio ROA berpengaruh positif signifikan terhadap kesehatan bank, berbanding terbalik dengan penelitian Welthi Sugiarti (2002), Titik Aryati dan Shirin Balalif (2007), Almilia dan Herdiningtyas (2005) bahwa variabel ROA tidak berpengaruh signifikan terhadap tingkat kesehatan bank.

H3: Rasio ROA secara parsial berpengaruh positif terhadap Kesehatan Bank.

\section{Pengaruh Rasio NIM terhadap kesehatan bank}

Rasio NIM, digunakan untuk mengukur kemampuan manajemen bank dalam mengelola aktiva produktifnya dalam menghasilkan laba bersih. Hasil penelitian Heru Laksito \& Nanang (2012) bahwa rasio NIM mempunyai pengaruh signifikan terhadap prediksi kondisi bermasalah pada bank. Semakin besar rasio NIM maka kemungkinan bank dalam kondisi bermasalah akan semakin kecil.

H4: Rasio NIM secara parsial berpengaruh positif terhadap Kesehatan Bank.

\section{Pengaruh Rasio BOPO terhadap kesehatan bank}

Rasio BOPO digunakan untuk mengukur kemampuan suatu manajemen bank dalam meminimalkan biaya operasional terhadap pendapatan operasional. Semakin kecil rasio BOPO berarti semakin efisien biaya operasional yang dikeluarkan bank sehingga semakin kecil kondisi bermasalah perbankan. Hasil penelitian Almilia dan Herdiningratyas (2005) bahwa variabel BOPO berpengaruh positif dan signifikan terhadap kondisi permasalahan perbankan.

H5: Rasio BOPO secara parsial berpengaruh positif terhadap Kesehatan Bank.

\section{Pengaruh Rasio FDR terhadap kesehatan bank}

Rasio FDR mengukur sejauh mana dana pinjaman yang bersumber dari dana pihak ketiga digunakan, semakin rendah FDR berarti efektivitas bank dalam meyalurkan pembiayaan masih kurang. Hasil penelitian Iwan Fakhruddin dan Tri Purwanti (2015) berpengaruh positif signifikan terhadap kinerja keuangan.

H6:Rasio FDR secara parsial berpengaruh positif terhadap Kesehatan Bank.

\section{Pengaruh CAR Terhadap Kesehatan Bank yang dimediasi dengan Pembiayaan}

Semakin besar rasio CAR suatu bank maka akan berpengaruh juga terhadap aktivitas pembiayaannya, dikarenakan bank mempunyai kemampuan dalam untuk menanggung risiko, seperti kredit macet yang dimungkinkan akan terjadi dan memanfaatkan aktivitas pembiayaan untuk memaksimalkan keuntungannya serta akan berdampak pada kesehatan perbankan juga (Ulin dan Astiwi, 2016;2). Rasio CAR memiliki pengaruh positif terhadap pembiayaan sesuai dengan penelitian Nurimansyah Setivia Bakti (2017) dimana semakin meningkat rasio CAR maka semakin meningkat juga pembiayaannya tentunya berdampak pada kesehatan bank tersebut. Dila Angraini (2018) melakukan penelitian tentang pengaruh 
DPK, NPF, Tingkat bagi hasil dan modal sendiri terhadap Profitabilitas dengan variabel intervening pembiayaan bagi hasil pada bank syariah dan didapat hasil bahwa variabel pembiayaan mampu memediasi NPF dan tingkat bagi hasil terhadap profitabilitas. Hal ini mengindikasikan kemungkinan pembiayaan juga memengaruhi hubungan antara rasio CAR terhadap kesehatan bank.

H7 : CAR berpengaruh positif terhadap Kesehatan Bank dengan dimediasi Pembiayaan

\section{Pengaruh NPFTerhadap Kesehatan Bank yang dimediasi dengan Pembiayaan}

Semakin tinggi rasio NPF dalam perbankan menandakan semakin besarnya pembiayaan bermasalah sehingga menimbulkan penurunan dalam memperoleh income dari pembiayaan tesebut, tentunya akan berdampak buruk pada kesehatan suatu perbankan. Maka dari itu bank harus berhati-hati dalam menyalurkan pembiayaannya, agar mampu meminimalisir risiko pembiayaan bermasalahnya (Ulin dan Astiwi, 2016;2) Sesuai dengan penelitian Nurimansyah Setivia Bakti (2017) bahwa rasio NPF mempunyai pengaruh negatif terhadap pembiayaan dimana semakin meningkat rasio NPF berarti semakin menurunnya pembiayaan sehingga berdampak pada kondisi kesehatan perbankan. Dila Angraini (2018) melakukan penelitian tentang pengaruh DPK, NPF, Tingkat bagi hasil dan modal sendiri terhadap Profitabilitas dengan variabel intervening pembiayaan bagi hasil pada bank syariah dan terdapat hasil bahwa variabel pembiayaan mampu memediasi NPF dan tingkat bagi hasil terhadap profitabilitas. Hal ini mengindikasikan kemungkinan pembiayaan juga memengaruhi hubungan antara rasio NPF terhadap kesehatan bank.

H8 : NPF berpengaruh negatif terhadap Kesehatan Bank dengan dimediasi Pembiayaan

\section{Pengaruh ROA Terhadap Kesehatan Bank yang dimediasi dengan Pembiayaan}

Semakin besar Rasio ROA menandakan bahwa bank mendapatkan laba yang tinggi dari aktivitas pembiayaan. Dengan adanya laba yang tinggi dari aktivitas tersebut maka kegiatan penyaluran kredit akan terus menerus dilakukan agar laba yang didapatkan semakin tinggi. Sesuai dengan hasil penelitian Yua Molek Winarti Putrid dan Alien Akmalia (2016) bahwa rasio ROA berpengaruh positif signifikan terhadap penyaluran pembiayaan dimana semakin tinggi ROA maka akan meningkatkan kegiatan pembiayaannya dan juga tingkat kesehatan perbankan. Dila Angraini (2018) melakukan penelitian tentang pengaruh DPK, NPF, Tingkat bagi hasil dan modal sendiri terhadap Profitabilitas dengan variabel intervening pembiayaan bagi hasil pada bank syariah dan mendapati hasil bahwa variabel pembiayaan mampu memediasi NPF dan tingkat bagi hasil terhadap profitabilitas. Hal ini mengindikasikan kemungkinan pembiayaan juga memengaruhi hubungan antara rasio ROA terhadap kesehatan bank.

H9 : ROA berpengaruh positif terhadap Kesehatan Bank dengan dimediasi Pembiayaan

\section{Pengaruh NIMTerhadap Kesehatan Bank yang dimediasi dengan Pembiayaan}

Rasio NIM adalah indikator untuk menilai efisiensi operasional suatu perbankan. NIM dihitung dengan perbandingan Pendapatan bunga bersih dengan rata-rata aktiva produktif. Berdasarkan penelitian Satrio dan Endang (2017) bahwa rasio NIM berpengaruh positif terhadap pembiayaan dimana semakin efektif bank dalam memanfaatkan aktiva produktif khususnya dalam bentuk kredit. Peningkatan pendapatan bunga bersih akan menyebabkan 
peningkatan dana pada perbankan dan penyaluran kredit juga meningkat sehingga kesehatan bank semakin baik. Dila Angraini (2018) melakukan penelitian tentang pengaruh DPK, NPF, Tingkat bagi hasil dan modal sendiri terhadap Profitabilitas dengan variabel intervening pembiayaan bagi hasil pada bank syariah dan mendapati hasil bahwa variabel pembiayaan mampu memediasi NPF dan tingkat bagi hasil terhadap profitabilitas. Hal ini mengindikasikan kemungkinan pembiayaan juga memengaruhi hubungan antara rasio NIM terhadap kesehatan bank.

H10: NIM berpengaruh positif terhadap Kesehatan Bank dengan dimediasi Pembiayaan

\section{Pengaruh BOPO Terhadap Kesehatan Bank yang dimediasi dengan Pembiayaan}

Rasio BOPO tidak terdapat pengaruh yang signifikan terhadap pembiayaan bank dalam jangka panjang maupun pendek. Rasio ini menggambarkan tingkat efisiensi bank dalam melakukan kegiatan operasionalnya. Tingkat efisiensi ini menunjukkan tingkat kesehatan suatu bank. Semakin kecil rasio ini bahwa bank memiliki tingkat mengefisienkan yang baik dimana beban operasional lebih sedikit dibandingkan dengan pendapatan operasional. Dalam teori The Liability Management Theory mengatakan bahwa bank mampu meningkatkan pembiayaan serta menjaga kepercayaan nasabah dengan memperbaiki likuiditas (dalam Satrio dan Endang, 2017). Sesuai dengan hasil penelitian Fauziyah Adzimanur, Sri Hartono dan Ranti Wiliasih (2015) bahwa rasio BOPO menunjukkan hasil yang tidak signifikan, dimana laba yang diperoleh bank tidak disalurkan dalam bentuk pembiayaan karena sumber dana yang disalurkan tersebut berasal dari dana pihak ketiga. Dila Angraini (2018) melakukan penelitian tentang pengaruh DPK, NPF, Tingkat bagi hasil dan modal sendiri terhadap Profitabilitas dengan variabel intervening pembiayaan bagi hasil pada bank syariah dan mendapati hasil bahwa variabel pembiayaan mampu memediasi NPF dan tingkat bagi hasil terhadap profitabilitas. Hal ini mengindikasikan kemungkinan pembiayaan juga memengaruhi hubungan antara rasio BOPO terhadap kesehatan bank.

H11: BOPO berpengaruh negatif terhadap Kesehatan Bank dengan dimediasi Pembiayaan

\section{Pengaruh FDR Terhadap Kesehatan Bank yang dimediasi dengan Pembiayaan}

FDR adalah indikator dalam mengukur likuiditas bank, dimana perbandingan antara pembiayaan dengan dana pihak ketiga. Sesuai dengan hasil penelitian Adzimatinur F, Hartoyo S dan Wiliasih R (2015) bahwa FDR memiliki pengaruh positif yang signifikan terhadap pembiayaan. Semakin tinggi FDR menandakan semakin tinggi tingkat pembiayaan yang disalurkan oleh bank dan berdampak pada semakin sehatnya suatu bank. Dila Angraini (2018) melakukan penelitian tentang pengaruh DPK, NPF, Tingkat bagi hasil dan modal sendiri terhadap Profitabilitas dengan variabel intervening pembiayaan bagi hasil pada bank syariah dan mendapati hasil bahwa variabel pembiayaan mampu memediasi NPF dan tingkat bagi hasil terhadap profitabilitas. Hal ini mengindikasikan kemungkinan pembiayaan juga memengaruhi hubungan antara rasio FDR terhadap kesehatan bank.

H12: FDR berpengaruh positif terhadap Kesehatan Bank dengan dimediasi Pembiayaan 


\section{METODE PENELITIAN}

Jenis penelitian ini tergolong dalam penelitian asosiatif dengan menggunakan metode kuantitatif. Penelitian asosiatif ialah penelitian dengan tujuan untuk mengetahui hubungan antara 2 variabel atau lebih. (Sugiyono, 2014;55-56)

\section{Populasi dan Sampel}

Populasi yang digunakan dalam penelitian ini adalah Bank Muamalat Syariah di Indonesia. Dalam penelitian ini sampel diambil dengan menggunakan metode Purposive Sampling, yaitu pengambilan sampel dalam suatu populasi berdasarkan kriteria tertentu. Kriteria yang digunakan adalah Bank Muamalat Syariah yang beroperasi di Indonesia. Bank Muamalat dimana telah memublikasikan laporan keuangannya dan telah memiliki kelengkapan data penelitian. Sampel yang digunakan dalam penelitian ini adalah laporan keuangan Bank Muamalat Indonesia mulai tahun 2009-2018 yang terpublikasikan, sehingga didapat 10 sampel laporan keuangan Bank Muamalat Indonesia.

\section{Pengukuran Variabel}

Fundamental perusahaan dalam penelitian ini diukur dengan menggunakan rasio-rasio keuangan yaitu rasio CAR, NPF, ROA, NIM, BOPO dan FDR terhadap kesehatan suatu bank dengan variabel intervening Pembiayaan. Rasio-rasio tersebut semuanya telah ada dalam laporan keuangan Bank Muamalat Syariah.

Rasio CAR (Capital Adequency Ratio), adalah membandingkan antara total modal dengan total Aktiva Tertimbang Menurut Ratio (ATMR), dengan formulasi berikut:

$\mathrm{CAR}=\frac{\text { Total Modal }}{\text { Aktiva Tertimbang Menurut Resiko }} \times 100 \%$

Non Performing Financing (NPF)

Rasio ini digunakan untuk mengukur kualitas asset. Rasio ini adalah perbandingan antara pembiayaan bermasalah terhadap total pembiayaan yang disalurkan. Semakin ketat kebijakan kredit suatu bank maka akan menurunkan tingkat pembiayaan masyarakat. Bank dapat dikatakan sehat jikalau NPF nya $<2 \%$. Adapun rumusnya yaitu:

Rasio NPF $=\frac{\text { Pembiayaan Bermasalah }}{\text { Total Pembiayaan }} \times 100 \%$

Rasio ROA (Return on Asset)

Rasio ini digunakan mengukur kemampuan bank dalam mendapatkan keuntungannya. Semakin tinggi nilai ROA maka semakin besar tingkat keuntungan yang diperoleh oleh bank. Adapun rumusnya sebagai berikut :

Rasio ROA $=\frac{\text { Laba Sebelum Pajak }}{\text { Total Aktiva }} \times 100 \%$ 


\section{Rasio NIM (Net Interest Margin)}

Rasio ini dihitung dengan perbandingan jumlah pendapatan bunga bersih dengan rata-rata aktiva produktif bank. Adapun rumusnya sebagai berikut :

$\mathrm{NIM}=\frac{\text { Pendapatan Bunga Bersih }}{\text { Rata-rata Aktiva Produktif }} \times 100 \%$

Rasio BOPO (Biaya Operasional Terhadap Pendapatan Operasional.

Rasio ini digunakan dalam mengukur kemampuan suatu bank dalam menjalankan kegiatan operasionalnya, semakin besar rasio ini, maka semakin tidak efisen biaya operasional yang dikeluarkan oleh bank. Rumus yang digunakan adalah :

Rasio BOPO $=\frac{\text { Beban Operasional }}{\text { Pendapatan Operasional }} \times 100 \%$

Rasio FDR (Financing to Deposit Ratio).

Rasio ini digunakan untuk mengukur kemampuan bank dalam melunasi kewajibannya dan membayar kembali kedeposannya. FDR yaitu rasio perbandingan antara pembiayaan yang diberikan dengan dana pihak ketiga, Bank bisa dikatakan sehat jika nilai FDR < 75\%, dengan rumus sebagai berikut:

Rasio FDR $=\frac{\text { Jumlah Kredit Yang Diberikan }}{\text { Jumlah Dana Pihak Ketiga }} \times 100 \%$

\section{Teknik Analisis}

Teknik analisis data yang digunakan dalam penelitian ini adalah Analisis jalur (Path Analysis) dan dilanjutkan dengan uji sobel dimana pengoperasian melalui program SPSS. Penelitian ini menguji pengaruh rasio-rasio keuangan yang meliputi CAR, NPF, ROA, NIM, BOPO dan FDR sebagai variabel independen terhadap kesehatan bank dengan pembiayaan sebagai variabel interveing. Sebelum melakukan pengujian data terlebih dahulu diuji normalitasnya, selanjutnya dilanjutkan pengujian secara simultan (Uji F), pengujian secara parsil (Uji t). Kemudian pengujian mediasi menggunakan analisis jalur.

\section{HASIL DAN PEMBAHASAN}

Penilaian terhadap tingkat kesehatan bank secara keseluruhan dilakukan dengan menggunakan analisis kuantitatif. Analisis kuantitatif yang digunakan meliputi pengujian normalitas, uji hipotesis dan uji mediasi. Adapun hasil dari penelitian ini diperoleh sebagai berikut :

Uji normalitas pada model regresi bisa dikatakan terdistribusi normal jika besaran nilai sig. Kolmogorov-Smirnov lebih besar dari ketentuannya yaitu sig.K-S $=0,05$. Pada penelitian ini masing-masing nilainya sebesar 0,991 untuk CAR, NPF sebesar 0.821, ROA sebesar 0,458, NIM sebesar 0,742, BOPO sebesar 0,531, FDR sebesar 0,878, Pembiayaan sebesar 0,572 dan kesehatan bank sebesar 0,998. Jadi kesimpulannya data tersebut memenuhi syarat normalitas. 


\section{Tabel 1.}

Hasil Statistik Deskriptif

\begin{tabular}{cccccc}
\hline & N & Minimum & Maximum & Mean & Std.Deviation \\
\hline CAR & 10 & 0,1110 & 0,1405 & 0,126600 & 0,0102007 \\
NPF & 10 & 0,0140 & 0,0485 & 0,028540 & 0,0124260 \\
ROA & 10 & 0,0008 & 0,0154 & 0,007020 & 0,0065139 \\
NIM & 10 & 0,0222 & 0,0524 & 0,040040 & 0,0111653 \\
BOPO & 10 & 0,8447 & 0,9824 & 0,935100 & 0,0552228 \\
FDR & 10 & 0,7318 & 0,9999 & 0,883820 & 0,0751861 \\
Pembiayaan & 10 & $1 . \mathrm{E} 10$ & $4, \mathrm{E} 10$ & $3,23 \mathrm{E} 10$ & $1,160 \mathrm{E} 10$ \\
Kesehatan Bank & 10 & 0,2374 & 0,8901 & 0,775950 & 0,0861595 \\
\hline
\end{tabular}

Sumber : Output SPSS 16

Variabel CAR mempunyai nilai minimum 0,1110 dan nilai maximum 0,1405 dengan rata-rata 0,126600 pada standar deviasi 0,0102007. Nilai rata-rata lebih besar dari pada standar deviasi menandakan bahwa data dalam variabel ini terdistribusi dengan baik. Variabel NPF mempunyai nilai minimum 0,0140 dan nilai maximum 0,0485 dengan rata-rata 0,028540 pada standar deviasi 0,0124260. Nilai rata-rata lebih besar dari pada standar deviasi menandakan bahwa data dalam variabel ini terdistribusi dengan baik. Variabel ROA mempunyai nilai minimum 0,0008 dan nilai maximum 0,0154 dengan rata-rata 0,007020 pada standar deviasi 0,0065139. Nilai rata-rata lebih besar dari pada standar deviasi menandakan bahwa data dalam variabel ini terdistribusi dengan baik.

Variabel NIM mempunyai nilai minimum 0,0222 dan nilai maximum 0,0524 dengan rata-rata 0,040040 pada standar deviasi 0,0111653 . Nilai rata-rata lebih besar dari pada standar deviasi menandakan bahwa data dalam variabel ini terdistribusi dengan baik. Variabel BOPO mempunyai nilai minimum 0,8447 dan nilai maximum 0,9824 dengan ratarata 0,935100 pada standar deviasi 0,0552228 . Nilai rata-rata lebih besar dari pada standar deviasi menandakan bahwa data dalam variabel ini terdistribusi dengan baik. Variabel FDR mempunyai nilai minimum 0,7318 dan nilai maximum 0,9999 dengan rata-rata 0,883820 pada standar deviasi 0,0751861. Nilai rata-rata lebih besar dari pada standar deviasi menandakan bahwa data dalam variabel ini terdistribusi dengan baik. Variabel Pembiayaan mempunyai nilai minimum 1.E10 dan nilai maximum 4,E10 dengan rata-rata 3,23E10 pada standar deviasi 1,160E10. Nilai rata-rata lebih besar dari pada standar deviasi menandakan bahwa data dalam variabel ini terdistribusi dengan baik. Variabel Kesehatan Bank mempunyai nilai minimum 0,2374 dan nilai maximum 0,8901 dengan rata-rata 0,775950 pada standar deviasi 0,0861595. Nilai rata-rata lebih besar dari pada standar deviasi menandakan bahwa data dalam variable ini terdistribusi dengan baik.

\section{Pengujian Hipotesis}

Uji F digunakan untuk mengetahui pengaruh variabel independen secara bersama-sama (simultan) terhadap variabel dependen. Uji F dilihat dari tabel anova, Pada penelitian ini dengan variabel independen $\mathrm{CAR}, \mathrm{NPF}, \mathrm{ROA}, \mathrm{NIM}, \mathrm{BOPO}, \mathrm{FDR}$ dan pembiayaan, sebesar 35,225 dengan nilai signifikansi 0,028<0,05. Berarti variabel independen secara bersamasama (simultan) berpengaruh signifikan terhadap kesehatan bank sebagai variabel 
dependen. Ini artinya bahwa fundamental perusahaan yang diwakilkan dengan rasio CAR, NPF, ROA, NIM, BOPO, dan FDR bahwa bank muamalat mampu menjaga dan memelihara kepercayaan masyarakat, dapat menjalankan fungsi intermediasi, serta dapat digunakan oleh pemerintah dalam menjalankan kebijakannya terutama kebijakan moneter.

Uji t digunakan untuk mengetahui seberapa jauh pengaruh variabel independen secara individual memengaruhi variabel dependen. Signifikansi yang digunakan adalah 5\% atau 0,05. Pada hipotesis pertama menghasilkan bahwa CAR tidak berpengaruh signifikan terhadap kesehatan bank berarti hipotesis pertama ditolak. Dimana menandakan bahwa besar kecilnya rasio kecukupan modal (CAR) belum tentu menyebabkan sehat tidaknya suatu perbankan. Bank dengan modal yang besar, tapi jika tidak mampu mempergunakan modalnya dengan baik untuk menghasilkan keuntungan maka modal tidak akan berpengaruh terhadap kesehatan bank dan itu akan sia sia. Bank yang sehat pasti bisa memanfaatkan modalnya dengan sangat efektif untuk menghasilkan keuntungan sebanyak-banyaknya. Hal ini tidak sesuai dengan teori yang menyatakan bahwa semakin tinggi CAR maka pendapatan juga naik serta prediksi kesehatan pun juga ikut naik. Pengaruh CAR yang menuju arah negatif dapat terjadi karena bank muamalat belum mampu memanfaatkan secara signifikan atas sumber tambahan modal lainnya sehingga pertumbuhan modal tidak mampu mengimbangi pertumbuhan aktiva produktif, dimana seharusnya dapat menambah laba serta dampaknya pada tingkat kesehatan bank dan berdampak juga terhadap kemampuan bank dalam melakukan ekspansi penyaluran dana. Hasil ini mendukung penelitian Titik Aryati dan Shirin Balafif (2007) yang menjelaskan CAR tidak berpengaruh terhadap kesehatan bank.

Pengajuan hipotesis kedua menunjukkan bahwa NPF mempunyai pengaruh negatif tidak signifikan berarti hipotesis kedua ditolak artinya semakin rendah rasio ini menunjukkan peningkatan kemampuan perbankan dalam mengelola pembiayaan bermasalahnya dan mengakibatkan peningkatan tingkat kepercayaan suatu investor terhadap bank serta berpengaruh baik pada kesehatan bank. Penelitian ini bertolak belakang dengan penelitian Diana Nurhayati dan Yuniningsih Yininingsih (2020) mengenai rasio NPF berdasarkan hasil analisis diskriminan bahwa rasio NPF mempunyai koefisien tertinggi dalam pembentukannya artinya mampu untuk mendeteksi tingkat kesehatan suatu perbankan.

Pengajuan hipotesis ketiga menunjukkan bahwa ROA mempunyai pengaruh negatif artinya semakin rendah rasio ini menandakan bahwa semakin besar dalam kondisi bermasalah atau tidak sehat. Rasio ROA mempunyai nilai sig lebih besar 0,05 berarti tidak terdapat pengaruh yang signifikan terhadap kesehatan bank sehingga hipotesis ketiga ditolak. Hasil penelitian ini tidak sesuai dengan teori yang menyatakan bahwa ROA memliki pengaruh positif terhadap tingkat kesehatan bank. Dimana semakin tinggi rasio ROA menandakan bahwa semakin kecil dalam kondisi bermasalah, kemampuan untuk meningkatkan pendapatan semakin besar sehingga kinerja bank bisa dikatakan baik dan tingkat kesehatan bank pun juga meningkat. Pengaruh ROA yang menuju kearah negatif dimungkinkan karena terdapat profitabilitas yang lebih banyak digunakan untuk menutupi kegagalan pembiayaan (beban-beban operasional) yang lebih besar dibandingkan laba yangt didapatkan. Hasil penelitian ini mendukung dari penelitian Titik Aryati dan Shirin Balafif (2007) Almilia dan Herdiningtyas (2005) bahwa variabel ROA tidak berpengaruh signifikan terhadap tingkat kesehatan bank.

Pengajuan hipotesis keempat menunjukkan bahwa NIM mempunyai pengaruh negatif artinya semakin rendah rasio ini menandakan bahwa semakin besar dalam kondisi 
bermasalah dan berdampak pada kesehatan suatu bank mengalami penurunan. Rasio NIM mempunyai nilai sig lebih besar dari 0,05 berarti tidak terdapat pengaruh yang signifikan terhadap kesehatan bank sehingga hipotesis keempat ditolak. Hasil ini mendukung penelitian Titik Aryati dan Shirin Balafif (2007) yang menjelaskan NIM tidak berpengaruh terhadap kesehatan bank.

Pengajuan hipotesis kelima bahwa variabel BOPO dengan nilai signifikansi 0,044 <0,05 dengan demikian bahwa variabel BOPO terdapat pengaruh yang signifikan terhadap kesehatan bank sehingga hipotesis kelima diterima. Nilai koefisien regresi rasio BOPO sebesar $-4,633$, arah koefisien dalam penelitian ini bertanda negatif, yang berarti bahwa semakin tinggi rasio BOPO maka akan semakin tinggi juga bank mengalami kondisi bermasalah, atau bisa dikatakan bahwa peningkatan biaya operasional lebih tinggi dibandingkan pendapatan operasionalnya sehingga laba yang didapatkan juga akan menurun dan predikat tingkat kesehatan bank juga menurun. Sebaliknya semakin kecil rasio tersebut maka semakin kecil bank dalam kondisi bermasalah, karena semakin efisien biaya operasional yang ditanggung oleh bank dan semakin sehat perbankan tersebut. Hasil penelitian ini sesuai dengan penelitian yang dilakukan oleh Almilia dan Herdiningratyas (2005) yang membuktikan bahwa variabel BOPO berpengaruh signifikan terhadap kesehatan bank.

Pengajuan hipotesis keenam bahwa variabel FDR mempunyai pengaruh positif artinya semakin rendah rasio ini menandakan bahwa semakin besar dalam kondisi bermasalah . hal ini disebabkan karena peningkatan pembiayaan yang diberikan dan dana yang dikeluarkan juga akan meningkat, dengan peningkatan jumlah dana yang diperlukan maka akan menambah beban operasional yang dikeluarkan oleh bank. Akibatnya keuntungan yang seharusnya dapat bertambah jadinya harus dialihkan kedana pembiayaan. Rasio FDR mempunyai nilai sig lebih besar dari 0,05 berarti tidak terdapat pengaruh yang signifikan terhadap kesehatan bank dan hipotesis keenam ditolak. Hasil ini mendukung penelitian Titik Aryati dan Shirin Balafif (2007) yang menjelaskan FDR tidak berpengaruh terhadap kesehatan bank.

Pada penelitian ini yang menguji pengaruh CAR, NPF, ROA, NIM, BOPO, FDR terhadap kesehatan bank sebagai variabel dependen bahwa secara parsial semua variabel tersebut tidak berpengaruh signifikan terhadap kesehatan bank kecuali variabel BOPO terdapat pengaruh yang signifikan. Variabel tersebut berarti tidak dapat digunakan untuk memprediksi kesehatan bank karena hasil regresi secara parsial menunjukkan tidak ada pengaruh antara variabel dependen terhadap kesehatan bank. Perbedaan hasil ini dengan penelitian lainnya dimungkinkan karena perbedaan sampel yang digunakan. Dengan demikian walaupun mendapatkan hasil yang tidak signifikan bukan berarti bank mengabaikan variabel-variabel tersebut dalam memengaruhi Kesehatan Bank. 
Thariq Atul Himah

Bank Health, Indonesian Muamalat Bank, Financing

Tabel 1.

Hasil Penelitian dengan Uji Path Analysis

\begin{tabular}{|c|c|c|c|c|}
\hline Variabel & S.E & $\beta$ & Sobel Test & Keterangan \\
\hline Konstanta & .347 & & & \\
\hline CAR & 1.124 & 0.081 & 0.183546 & Diterima \\
\hline $\mathrm{NPF}$ & 1.273 & -0.644 & -0.412206 & Diterima \\
\hline $\mathrm{ROA}$ & 6.122 & -0.950 & -0.95172 & Ditolak \\
\hline NIM & 2.983 & -0.251 & 1.173582 & Diterima \\
\hline BOPO & .424 & -1.260 & -0.427656 & Diterima \\
\hline FDR & .200 & 0.213 & 0.52839 & Diterima \\
\hline
\end{tabular}

Sumber : diolah (2020)

Uji mediasi (intervening) pada penelitian ini menggunakan analisis jalur dan uji sobel. Pengujian hipotesis kedelapan menunjukkan bahwa pengaruh tidak langsung variabel CAR terhadap pembiayaan melalui analisis jalur sebesar 0,184 nilai tersebut lebih besar daripada koefisien pengaruh langsung yang sebesar 0,081 hal ini menunjukkan bahwa secara tidak langsung variabel CAR melalui Pembiayaan mempunyai pengaruh signifikan terhadap Kesehatan bank sehingga hipotesis kedelapan diterima. Tingkat rasio CAR yang tinggi menandakan tingkat permodalan yang memadai. Dimana dampaknya nanti, kemampuan suatu perbankan dalam menanggung risiko semakin besar dari pembiayaan yang tersalurkan, sehingga membuat perbankan semakin dapat meningkatkan pinjamannya, yang berakibat semakin meningkatnya kinerja suatu perbankan.

Pengujian hipotesis kesembilan menunjukkan bahwa pengaruh tidak langsung variabel NPF terhadap kesehatan bank melalui analisis jalur sebesar -0,412, nilai tersebut lebih besar daripada koefisien pengaruh langsung yang sebesar $-0,644$ hal ini menunjukkan bahwa secara tidak langsung variabel NPF melalui pembiayaan mempunyai pengaruh signifikan terhadap kesehatan bank dan hipotesis kesembilan ditolak. NPF menunjukkan kemampuan suatu manajemen perbankan dalam mengolah pembiayaan bermasalahnya. Tingginya NPF, diartikan risiko atau pembiayaan bermasalah yang dimiliki semakin besar, sehingga menimbulkan penurunan dalam memperoleh income dari pembiayaan dan tentunya akan berakibat menurunnya kinerja perbankan sehingga kondisi kesehatan bank juga turun. Maka dari itu bank harus berhati-hati dalam menyalurkan pembiayaannya agar mampu meminimalisir risiko pembiayaan bermasalahnya. Hasil penelitian ini bahwa pembiayaan mampu memediasi NPF terhadap kesehatan bank.

Pengujian hipotesis kesepuluh menunjukkan bahwa pengaruh tidak langsung variabel ROA terhadap kesehatan bank melalui analisis jalur sebesar -0,951, nilai tersebut lebih kecil daripada koefisien pengaruh langsung yang sebesar -0,950 hal ini menunjukkan bahwa secara tidak langsung variabel ROA melalui pembiayaan tidak mempunyai pengaruh signifikan terhadap kesehatan bank sehingga hipotesis kesepuluh ditolak. Semakin besar Rasio ROA menandakan bahwa bank mendapatkan laba yang tinggi dari aktivitas pembiayaan. Dengan adanya laba yang tinggi dari aktivitas tersebut maka kegiatan penyaluran kredit akan terus menerus dilakukan agar laba yang didapatkan semakin tinggi. Semakin tinggi laba perusahaan, maka tingkat pengembalian (return) saham pun juga tinggi. Profitabilitas yang tinggi semakin menarik investor untuk berinvestasi pada perusahaan tersebut sehingga dapat meningkatkan harga saham meningkat dan dampaknya pada kesehatan bank juga (Bernadetta dan Abriandi, 2019;9). 
Pengujian hipotesis kesebelas menunjukkan bahwa pengaruh tidak langsung variabel NIM terhadap kesehatan bank melalui analisis jalur sebesar 1,173, nilai tersebut lebih besar daripada koefisien pengaruh langsung yang sebesar -0,251 hal ini menunjukkan bahwa secara tidak langsung variabel NIM melalui pembiayaan mempunyai pengaruh signifikan terhadap kesehatan bank dan hipotesis kesebelas diterima. Tingginya rasio NIM, diartikan semakin meningkatkan pendapatan bunga atas aktiva produktif yang telah dikelola oleh bank sehingga bank dalam kondisi bermasalah semakin kecil dan semakin baik kesehatan bank.

Pengujian hipotesis keduabelas menunjukkan bahwa pengaruh tidak langsung variabel BOPO terhadap kesehatan bank melalui analisis jalur sebesar -0.427 , nilai tersebut lebih besar daripada koefisien pengaruh langsung yang sebesar -1,260 hal ini menunjukkan bahwa secara tidak langsung variabel BOPO melalui pembiayaan mempunyai pengaruh signifikan terhadap kesehatan bank dan hipotesis kedua belas ditolak. Nilai BOPO yang semakin kecil menunjukkan bahwa bank memiliki tingkat mengefisienkan yang tinggi dimana beban operasional lebih sedikit dibandingkan pendapatan operasional. Tingkat keefisienan bank menunjukkan tingkat kesehatan bank. Bank mampu meningkatkan pembiayaan serta menjaga kepercayaan nasabah dengan memperbaiki likuiditasnya (dalam Satrio dan Endang, 2017).

Pengujian hipotesis ketiga belas menunjukkan bahwa pengaruh tidak langsung variabel FDR terhadap kesehatan bank melalui analisis jalur sebesar 0,528, nilai tersebut lebih besar daripada koefisien pengaruh langsung yang sebesar 0,213 hal ini menunjukkan bahwa pembiayaan mampu memediasi pengaruh FDR terhadap kesehatan bank dan hipotesis ketiga belas diterima. Tingkat FDR yang tinggi, mengindikasikan pembiayaannya semakin tinggi. Artinya kondisi ini terjadi karena semakin banyaknya dana yang terhimpun, maka akan semakin banyaknya dana yang tersalurkan juga. Dengan kata lain, bank mampu melunasi hutang-hutangnya dan membayar kembali deposannya. Dimana bila kondisi FDR berada tahap aman, dengan semakin banyaknya pembiayaan maka akan meningkatkan kinerja perbankan dan bank dalam kondisi sehat.

Hasil pengujian Path Analysis menunjukkan bahwa Pembiayaan dapat memediasi secara signifikan pada hubungan Fundamental Perusahaan terhadap Kesehatan Bank. Hal ini Bank Muamalat dalam melakukan kegiatan penyaluran pembiayaannya dapat menentukan profitabilitas dan Kinerja yang baik sehingga Kesehatan Bank juga dipastikan akan sehat.

\section{KESIMPULAN}

Penelitian ini dilakukan untuk mengetahui pengaruh fundamental perusahaan yang diukur dengan rasio-rasio keuangan perusahaan terhadap kesehatan bank, serta mengetahui apakah pembiayaan dapat memediasi hubungan fundamental perusahaan dengan kesehatan bank pada Bank Muamalat periode 2009-2018. Berdasarkan hasil penelitian ini, maka dapat disimpulkan sebagai berikut : pertama, fundamental perusahaan yang diukur dengan rasiorasio keuangan secara parsial tidak berpengaruh signifikan terhadap kesehatan bank. Kedua, fundamental perusahaan yang diukur dengan rasio-rasio keuangan secara simultan berpengaruh signifikan terhadap kesehatan bank. Ketiga, pembiayaan dapat memediasi pengaruh fundamental perusahaan terhadap kesehatan bank.

\section{Implikasi Praktis / Teoritis}

Bank Muamalat Syariah diharapkan dapat mengelola asetnya menjadi lebih maksimal agar dapat menghasilkan laba, tingkat kepercayaan, kinerja perusahaan, nilai perusahaan dimana 
dampaknya pada kesehatan bank akan mengalami kenaikan juga. Manajemen bank harus lebih maksimal lagi meningkatkan rasio ROA karena semakin besar rasio ROA menandakan bahwa bank mendapatkan laba yang tinggi dari aktivitas pembiayaan. Dengan adanya laba yang tinggi dari aktivitas tersebut maka kegiatan penyaluran kredit akan terus menerus dilakukan agar mendapatkan laba semakin tinggi mengingat rasio ROA tidak berpengaruh terhadap kesehatan walaupun diperkuat dengan adanya variabel mediasi.

Penelitian ini masih memiliki keterbatasan berupa jumlah variabel yang diteliti. Diharapkan bagi peneliti selanjutnya dapat menambahkan variabel lain yang berhubungan dengan tingkat kesehatan bank atau dapat menggunakan variabel intervening lain selain pembiayaan dalam memperkuat kesehatan perbankan, serta dapat melakukan penelitian pada sektor yang berbeda sehingga hasilnya lebih maksimal.

\section{REFERENSI}

Adzimatinur, F., Hartoyo, S., \& Wiliasih, R. (2015). Faktor-Faktor yang Memengaruhi Besaran Pembiayaan Perbankan Syariah di Indonesia. Al-Muzara'ah, 3(2), 106-121.

Aryani, T \& Balafif, S. (2007). Analisis Faktor Yang Memengaruhi Tingkat Kesehatan Bank Dengan Regresi Logit. Jurnal The Winners, 8(2), 122

Bakti, N. S. (2017). Analisis DPK, CAR, ROA dan NPF terhadap pembiayaan pada perbankan syariah. Jurnal Bisnis dan Manajemen (Journal of Business and Management), 17(2), 15-28.

Fakhruddin, I., \& Purwanti, T. (2015). Pengaruh Rasio Kesehatan Bank Terhadap Kinerja Keuangan Bank Syariah Periode 2010-2013. Kompartemen: Jurnal Ilmiah Akuntansi, $13(2)$.

Ginting, R. (2012). Kodifikasi Peraturan Bank Indonesia Kelembagaan Tingkat Kesehatan Bank. Jakarta: Pusat Riset dan Edukasi Bank Sentral (PRES) Bank Indonesia.

Harahap, S. S., \& Yusuf, M. (2010). Akuntansi perbankan syariah. LPFE Usakti.

Herdinigtyas, W., \& Almilia, L. S. (2005). Analisis rasio CAMEL terhadap prediksi kondisi bermasalah pada lembaga perbankan perioda 2000-2002. Jurnal Akuntansi dan keuangan, 7(2), 131-147.

Kasmir. (2008). Analisis La poran Keuangan. Jakarta: PT Raja Grafindo

Nanang N. (2016). Model Prediksi Tingkat Kesehatan Bank melalui rasio Camels. Jurnal Akuntansi Indonesia, 1(1), 20-29

Novita, B. D., \& Abriandi, A. (2019). Analisis Pengaruh Profitabiltas dan Ukuran Perusahaan terhadap Stock Return dengan Income Smoothing sebagai Variabel Moderasi. AKURASI: Jurnal Riset Akuntansi dan Keuangan, 1(1), 1-12.

Nurhayati, D., \& Yuniningsih, Y. Analisis Kesehatan Bank Dengan Metode CAMELS Pada Perbankan Umum Syariah Periode 2014-2018. Jurnal MANOVA, 2(1), 9

Nurhayati, S. (2011). Wasilah, Akuntansi Syariah di Indonesia. Jakarta: Salemba Empat.

Pratami, W. A. N., \& Muharam, H. (2011). Analisis Pengaruh Dana Pihak Ketiga (Dpk), Capital Adequacy Ratio (Car), Non Performing Financing (Npf) Dan Return On Asset (Roa) Terhadap Pembiayaan Pada Perbankan Syariah (Studi Kasus Pada Bank Muamalat Indonesia Periode 2001-2011) (Doctoral dissertation, Universitas Diponegoro).

Pratiwi, S., \& Hindasah, L. (2014). Pengaruh Dana Pihak Ketiga, Capital Adequacy Ratio, Return nn Asset, Net Interest Margin dan Non Performing Loan Terhadap Penyaluran Kredit Bank Umum di Indonesia. Jurnal Manajemen Bisnis, 5(2), 192-208.

Putri, Y. M. W. (2016). Pengaruh CAR, NPL, ROA dan LDR terhadap Penyaluran Kredit pada Perbankan (Studi pada Perusahaan Perbankan yang Listed di Bursa Efek Indonesia Periode 2011-2015). BALANCE: Economic, Business, Management and Accounting Journal, 13(02).

Setiawan, U. N. A., \& Indriani, A. (2016). Pengaruh Dana Pihak Ketiga (DPK), Capital Adequacy Ratio (CAR), dan Non Performing Financing (NPF) terhadap Profitabilitas Bank 
Syariah dengan Pembiayaan sebagai Variabel Intervening. Diponegoro Journal of Management, 5(4), 121-131.

Somad, D. Z., Rachma, N., \& Rizal, M. (2020). Analisis Tingkat Kesehatan Perbankan Dengan Metode Camels Terhadap Kinerja Perbankan Syariah Dan Konvensional (Study Kasus Pada Perusahaan Perbankan Syariah dan Konvensional Milik Pemerintah Yang Terdaftar Di Bursa Efek Indonesia Periode 2015-2018). Jurnal Ilmiah Riset Manajemen, 9(05).

Sugiyono. (2017). Metode Penelitian Kuantitatif Kualitatif dan R\&D. Bandung: Alfabeta.

\section{DECLARATIONS}

\section{Funding}

The authors received no financial support for the research and publication of this article.

\section{Conflicts of interest/ Competing interests:}

The authors have no conflicts of interest to declare that are relevant to the content of this article.

\section{Data, Materials and/ or Code Availability:}

Data sharing is not applicable to this article as no new data were created or analyzed in this study.

\section{Notes on Contributor}

Thariq Atul Himah adalah Mahasiswa jurusan Akuntansi Syariah dari IAIN Tulungagung. Penulis melakukan penelitian ini sebagaimana digunakan untuk syarat kelulusan atau guna untuk memperoleh gelar Sarjana S1 Ekonomi di IAIN Tulungagung. Thariq Atul Himah dapat dihubungi di: thoriqatul@gmail.com

\section{How to cite this Article}

Himah, T. (2021). Pengaruh Fundamental Perusahaan Terhadap Kesehatan Bank Melalui Pembiayaan Pada Bank Muamalat Syariah. AKURASI: Jurnal Riset Akuntansi Dan Keuangan, 3(1), 1 - 16 